\title{
Surveillance summary reporting guide
}

\section{Correspondence: ccdr-rmtc@phac-aspc.gc.ca}

Surveillance reports provide essential information about a disease or health-related condition according to person, time and place. They often provide the basis to identify burden of illness and may include related information, such as trends in risk factor frequency or prescribing practices. Surveillance reports inform strategies to address targeted health conditions and may identify the need for additional clinical care or public health action. They can be summaries of larger reports published in the grey literature and, increasingly, may link to a complete surveillance dataset. Surveillance reports are approximately 2,000-2,500 words in length - excluding the abstract, tables and references.

The Canada Communicable Disease Report (CCDR) supports the use of reporting guidelines, including those collected by the Enhancing the QUAlity and Transparency Of health Research (EQUATOR) Network (1). However, the EQUATOR Network does not currently provide guideline for surveillance reports, so the CCDR has developed this one based on other checklists, a guideline for evaluating surveillance systems (2) and recent trends in Open Science.

Table 1 provides CCDR's checklist for surveillance reports. Figure 1 illustrates an example of how surveillance data is typically summarized graphically with incidence on the $y$ axis and time on the $x$ axis.

As with all submissions, check CCDR's Information for authors (published in January every year with the first issue of each new volume) for general manuscript preparation and submission requirements.

\section{Table 1: Checklist for surveillance reports}

\begin{tabular}{|c|c|c|}
\hline Reporting item & $N^{01}$ & Description \\
\hline \multicolumn{3}{|l|}{ Title } \\
\hline Title & 1 & $\begin{array}{l}\text { Compose a title that includes the name of the health condition, population, time } \\
\text { and place. }\end{array}$ \\
\hline \multicolumn{3}{|l|}{ Abstract } \\
\hline Structured summary & 2 & $\begin{array}{l}\text { Provide a structured abstract including the following sub-headings: Background; } \\
\text { Objectives; Methods; Results; and Conclusions. }\end{array}$ \\
\hline \multicolumn{3}{|l|}{ Introduction } \\
\hline Context & 3 & $\begin{array}{l}\text { Summarize the current situation regarding the health condition under } \\
\text { surveillance and identify why it is important. }\end{array}$ \\
\hline Objectives & 4 & State the objective of the surveillance report. \\
\hline \multicolumn{3}{|l|}{ Methods } \\
\hline Setting & 5 & Describe the setting, locations and dates of the surveillance period. \\
\hline Population & 6 & Describe the population under surveillance. \\
\hline Definitions & 7 & $\begin{array}{l}\text { Provide definitions for each health event under surveillance, including case } \\
\text { definitions and any public health interventions. }\end{array}$ \\
\hline Information sources & 8 & $\begin{array}{l}\text { Describe all data sources, including the objective of any surveillance systems, } \\
\text { what data were collected and how data were gathered, transferred and stored. }\end{array}$ \\
\hline Supplementary data & 9 & $\begin{array}{l}\text { If appropriate, note where to access supplemental material (e.g., } \\
\text { www.opendata.gc.ca). }\end{array}$ \\
\hline $\begin{array}{l}\text { Data quality, missing } \\
\text { data and reporting } \\
\text { delays. }\end{array}$ & 10 & $\begin{array}{l}\text { Describe how the data quality was assessed. } \\
\text { Explain how missing data were addressed. } \\
\text { If data is reported by date of diagnosis or symptom onset, include a statement }\end{array}$ \\
\hline
\end{tabular}




\begin{tabular}{|c|c|c|}
\hline & & about whether the data for the most recent periods may be revised. \\
\hline Data analysis & 11 & $\begin{array}{l}\text { Describe any analytical methods used providing sufficient detail to enable a } \\
\text { knowledgeable reader with access to the original data to judge its } \\
\text { appropriateness and to assess the reported results. }\end{array}$ \\
\hline \multicolumn{3}{|l|}{ Results } \\
\hline Descriptive data & 12 & Provide a summary of the descriptive data, including demographics. \\
\hline Data Quality & 13 & Report on data quality (e.g., completeness, missing data, under reporting,) \\
\hline Analytic data & 14 & $\begin{array}{l}\text { Provide a summary of the analysis including (when indicated) estimates of } \\
\text { trends. When applicable, point estimates should include appropriate indicators of } \\
\text { measurement error such as } 95 \% \text { confidence intervals (e.g., average annual } \\
\text { percentage change used to describe trends or odds ratios used to describe } \\
\text { subgroup differences). }\end{array}$ \\
\hline Figures & 15 & $\begin{array}{l}\text { Create the minimum number of figures to highlight key results. } \\
\text { Create a title that includes person, time and place. }\end{array}$ \\
\hline \multicolumn{3}{|l|}{ Discussion } \\
\hline Key results & 16 & Summarise key results with reference to study objectives \\
\hline Comparison & 17 & Consider these findings in relation to the current literature. \\
\hline $\begin{array}{l}\text { Strengths and } \\
\text { weaknesses }\end{array}$ & 18 & $\begin{array}{l}\text { Discuss strengths and weaknesses of the study (data quality, completeness, } \\
\text { sources of potential bias). }\end{array}$ \\
\hline $\begin{array}{l}\text { Interpretation and } \\
\text { generalizability }\end{array}$ & 19 & $\begin{array}{l}\text { Provide a cautious overall interpretation of results considering objectives, } \\
\text { limitations, multiplicity of analyses, results from similar studies and other relevant } \\
\text { evidence. }\end{array}$ \\
\hline Conclusion & 20 & Ensure conclusions address objective and follow from the results. \\
\hline
\end{tabular}


Figure 1: Rates of reported cases of Hepatitis C in Canada ${ }^{1}$ by sex, CNDSS ${ }^{2}, 1991-2012$ (3)

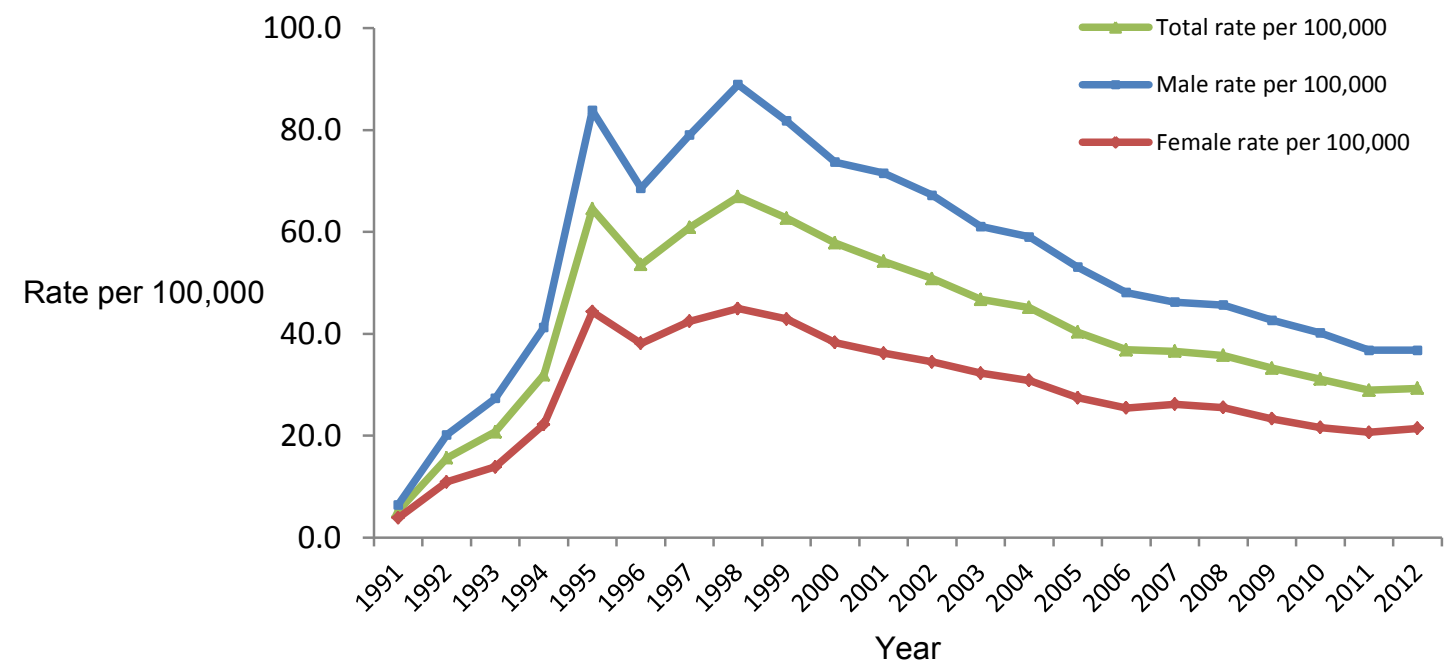

${ }^{1}$ Includes PEI, ON, SK, AB, BC 1991-2012; NL, NB, NT 1993-2012; YT 1994-2012; NS, QC 1996-2012; MB 1999-2012; NU 1999-2006. For rate calculation, population denominators were adjusted to include only those jurisdictions for which data were available in a given year.

${ }^{2}$ CNDSS $=$ Canadian Notifiable Disease Surveillance System

\section{References}

(1) The Equator Network (Enhancing the QUality and Transparency of health Research)[Internet]. Oxford: EQUATOR Network; 2015.

http://www.equator-network.org/.

(2) Klaucke DN, Buehler JW, Thacker SB, Parrish RG, Trowbridge FL, Berkelman RL and the Surveillance Coordination

Group. Guidelines for evaluating surveillance systems. MMWR. 1988;37(S-5):1-18.

(3)

Payne E, Totten S, Archibald C. Hepatitis C surveillance in Canada. CCDR 2014;19:421-428. 